\title{
KOMPONEN HASIL UMBI DAN KANDUNGAN FISIKOKIMIA 43 GENOTIP UBI JALAR BERDAGING UMBI JINGGA PADA PENANAMAN DI LAHAN KERING DAN LAHAN BASAH
}

\section{Storage Root Yield Component and Physico-chemical Content 48 Orange-Fleshed Sweetpotato Genotypes on Upland and Rice Field Cultivation}

\author{
Hanny Hidayati Nafi'ah ${ }^{1)}$, Tati Nurmala ${ }^{2)}$, Agung Karuniawan ${ }^{3)}$, dan Budi \\ Waluyo $^{4)}$ \\ 1) Fakultas Pertanian Universitas Garut, Indonesia \\ Jalan Raya Samarang No. 52 A Garut \\ ${ }^{2,3)}$ Fakultas Pertanian Universitas Padjadjaran, Bandung, Indonesia \\ Jalan Raya Bandung Sumedang Km.21 Jatinangor 45363 \\ 4) Fakultas Pertanian Universitas Brawijaya, Malang, Indonesia \\ Jalan Veterann Malang 65145 \\ Email : hanny.hidayati@uniga.ac.id
}

\begin{abstract}
ABSTRAK
Ubi jalar berdaging jingga potensial untuk bahan pangan karena mengandung karbohidrat, untuk pangan fungsional karena mengandung beta karoten dan untuk industri karena bisa dijadikan pati dan alkohol. Ada 43 genotip ubi jalar berdaging jingga yang telah terseleksi dari penelitian pendahuluan untuk diuji komponen hasil umbi dan kandungan fisikokimianya di lahan kering dan lahan basah yang bertujuan untuk melihat perbedaan karakter genotip pada kedua agroekosistem. Metode yang digunakan adalah Augmented design tahap I dengan 5 check. Blok percobaan dibagi menjadi 4 (empat) blok, plot berbentuk guludan dengan panjang 5 meter dan lebar 1 meter. Hasil penelitian menunjukkan ada perbedaan respon karakter pada 43 genotip ubi jalar berdaging jingga di laha tegalan dan lahan bekas sawah. Karakter yang menjadi penciri spesifik adalah karakter pada sektor $\mathrm{V}$ adalah jumlah umbi per plot (G), pada sektor ini genotip yang beragam ada 17 genotip di lahan tegalan, yaitu 194 (276), 186 (322), 193 (275), 199 (294), 195 (281), 42 (10), 217 (493), 219 (473), 190 (350), 201 (295), 28 (106), 110 (237), 117 (240), 112 (232), 119 (247), 203 (290), dan 113 (222). Sedangkan di lahan bekas sawah tidak ada genotip yang beragam. Genotip dengan jumlah rata-rata
\end{abstract}


karakter tertinggi paling banyak adalah 224 (399b), 42 (10), dan 199 (294) yaitu masing-masing 17, 16, dan 15.

Kata kunci : Ubi jalar jingga, beta karoten, lahan basah, lahan kering.

\begin{abstract}
Orange-fleshed sweet potato potential for food because it contains carbohydrates, potential for functional food that contains beta carotene and the potential for the industry because it can be used as starch and alcohol. There are 43 genotypes of orange-fleshed sweet potato that has been selected from the preliminary study to test components of the tuber yield and physicochemical content on dry land and rice field that aims to see the difference in the character of genotypes at both agro-ecosystem. The method used is Augmented design phase I with 5 check. Blocks were divided into 4 (four) blocks, shaped plot mounds with a length of 5 meters and a width of 1 meter. The results showed no differences in response character at 43 genotypes orange fleshed sweet potato on dry land and rice fields. Characters that characterize the specific is a character in sector $V$ is the number of tubers per plot $(G)$, the sector genotype variations there are 17 genotypes on dry land, namely 194 (276) 186 (322) 193 (275), 199 ( 294), 195 (281), 42 (10), 217 (493) 219 (473) 190 (350) 201 (295) 28 (106) 110 (237) 117 (240), 112 ( 232), 119 (247) 203 (290), and 113 (222). While in the rice field was no genotyping diverse. Genotypes with the average number of characters at the most highest is 224 (399b), 42 (10), and 199 (294), respectively 17, 16 and 15.
\end{abstract}

Keyword: Orange-fleshed sweet potato, functional food, genotype variations

\title{
PENDAHULUAN
}

Ubi jalar merupakan salah satu umbi-umbian yang banyak ditanam di Indonesia. Produksi ubi jalar pada tahun 2014 mencapai 2.382.025 t. Sentra ubi jalar Indonesia berada di empat Provinsi, produksi tertinggi di Provinsi Jawa Barat mencapai 471.737 t, selanjutnya Papua 412.878 t, Jawa Timur 312.449 t, dan Jawa Tengah 179.393 t (Biro Pusat Statistik, 2014). Konsumsi ubi jalar mencapai $6,3 \mathrm{~kg} / \mathrm{kapita} / \operatorname{tahun}$ (Karuniawan, dkk, 2012).

Plasma nutfah ubi jalar lokal Jawa Barat potensial untuk bahan pangan, pangan fungsional dan industri (Waluyo, dkk, 2011), salah satunya adalah ubi jalar berdaging jingga. Ubi jalar memiliki nilai ekonomis karena selain sumber pangan karena mengandung karbohidrat 80 - 90\% per basis kering, mineral seperti K, Na, Cl, P, Ca serta vitamin A, B, C (Palmer, 1982; Onwueme and Sinha, 1991), juga dapat dijadikan sebagai sumber pangan fungsional karena 
kandungan betakaroten mencapai $4.629 \mu \mathrm{g} / 100 \mathrm{~g}$ basis basah (Balitkabi, 2012) dan bahan baku industri pati dan alkohol (Ukom et al., 2009), karena mempunyai karakteristik yang sesuai untuk dijadikan sebagai bahan baku industri (Brabet et al., 1998; Katayama et al., 2000, 2006; Huang et al., 2005).

Ada 20 varietas unggul yang telah dilepas oleh Balai Penelitian Kacang dan Umbi, namun hanya 4 varietas yang berwarna daging jingga (Balitkabi, 2012). Karena itu seleksi genotip ubi jalar berdaging jingga untuk dijadikan varietas unggul perlu dilakukan. Seleksi dilakukan berdasarkan komponen hasil dan kandungan fisikokimia ubi jalar yang ditanam di dua agroekosistem yang berbeda, yaitu lahan kering dan lahan basah.

Lahan kering dapat diartikan sebagai lahan yang digunakan untuk usaha pertanian dengan menggunakan air secara terbatas dan biasanya hanya mengharapkan dari curah hujan atau menunggu musim hujan. Lahan ini mempunyai kondisi agro-ekosistem yang beragam, pada umumnya berlerang dan dengan kondisi kemantapan lahan yang labil (peka terhadap erosi) terutama bila pengelolaannya tidak memperhatikan kaidah konservasi tanah (Notohadiprawiro, 2006). Lahan basah dicirikan oleh muka air tanah yang relatif dangkal, dan juga dekat dengan permukaan tanah, pada waktu yang cukup lama sepanjang tahun untuk menumbuhkan hidrofita, yaitu tumbuh-tumbuhan yang khusus tumbuh di wilayah basah. Lahan basah ini merupakan wilayah yang memiliki tingkat keanekaragaman hayati yang tinggi dibandingkan dengan lahan kering (Puspita, dkk, 2005).

Tanggapan suatu genotip ubi jalar pada umumnya beragam bila di uji pada agroekosistem yang berbeda hal ini disebabkan karena ada interaksi antara genotip dan lingkungan. Hal ini menunjukkan bahwah pengembangan ubi jalar dilahan sawah sesudah padi yang kemampuan mengikat airnya tinggi akan berbeda hasilnya bila dibandinggkan dengan lahan kering atau ladang yang kemampuan mengikat airnya rendah (Jusuf, dkk., 2002).

\section{METODE}

Percobaan dilaksanakan di Kebun Percobaan Universitas Padjadjaran Ciparanje Jatinangor, Kabupaten Sumedang, Provinsi Jawa Barat. Lokasi percobaan merupakan lahan kering dan lahan bekas sawah irigasi yang berada pada ketinggian $720 \mathrm{~m}$ dpl, dengan rata-rata curah hujan $175,3 \mathrm{~mm}$ per dan suhu harian 18, $1^{\circ} \mathrm{C}$. Percobaan dimulai pada 15 Februari dan berakhir 5 Juli 2014.

Percobaan dilakukan dengan menggunakan Augmented Design I, berdasarkan rancangan ini, terdapat genotip yang diuji (new selection) dan varietas pembanding atau kontrol (check) (Petersen, 1994). Genotip yang diuji sebanyak 43 genotip yang terdiri dari warna jingga dan varietas pembanding adalah yaitu CIA, Shiroyutaka, Ayamurasaki, Rancing, dan Kuput. 
Blok percobaan dibagi menjadi 4 (empat) blok, plot berbentuk guludan dengan panjang 5 meter dan lebar 1 meter. Jarak antar guludan $50 \mathrm{~cm}$ dengan kedalaman $40 \mathrm{~cm}$. Genotip yang akan diuji ditempatkan pada blok secara acak dan tanpa pengulangan, sehingga setiap genotip hanya akan muncul satu kali dalam satu blok. Varietas pembanding akan diulang pada setiap blok dengan penempatan yang acak.

Setiap genotip ditanam satu baris per plot dengan jarak tanam $25 \mathrm{~cm}$ dalam barisan. Pada setiap lubang tanam ditanami stek batang ubi jalar dengan panjang sekitar $20 \mathrm{~cm}$ yang ditanam berbentuk L dengan arah serempak, ini bertujuan agar arah pertumbuhan akar serempak. Lubang tanam dibuat dengan kedalaman $5 \mathrm{~cm}$.

Pengamatan yang dilakukan pada saat panen adalah : panjang umbi $(\mathrm{cm})$, diameter umbi $(\mathrm{cm})$, jumlah umbi per tanaman, bobot umbi per tanaman $(\mathrm{kg})$, jumlah umbi ekonomis per tanaman, bobot umbi ekonomis per tanaman $(\mathrm{kg})$, jumlah umbi per plot, bobot umbi per plot $(\mathrm{kg})$. Pengamatan yang dilakukan di Laboratorium adalah : kadar air (\% FW), kandungan pati (\% FW), dan kandungan gula reduksi (\% FW). Data yang dikonversi adalah : hasil umbi (t/ha), bobot 10 umbi (kg), kandungan berat kering (\% FW), hasil kandungan berat kering (t/ha), hasil kadar air ( $\mathrm{t} / \mathrm{ha}$ ), hasil kandungan pati ( $\mathrm{t} / \mathrm{ha}$ ), dan hasil kandungan gula reduksi (t/ha).

Respon spesifik genotip terhadap komponen hasil dan karakter fisikokimia akan ditampilkan dengan metode GT biplot (Genotype Traits biplot). GT biplot adalah metode yang efektif untuk mengkaji data dengan multi karakter karena data genotip dan karakter ditampilkan dengan bentuk grafik, sehingga memungkinkan untuk mengetahui hubungan antara karekter-karekter genotip dan profil karakter genotip (Yan dan Kang, 2003). Analisis dan perhitungan biplot genotip x karakter mengadopsi metode biplot yang digunakan Zanetta (2014).

\section{HASIL DAN PEMBAHASAN}

Tabel 1 menunjukkan rata-rata penampilan karakter hasil dan komponen hasil 48 genotip ubi jalar berdaging umbi jingga pada lahan tegalan dan lahan sawah. Penampilan karakter ubi jalar yang ditanam di lahan tegalan lebih baik dibandingkan di lahan bekas padi, karakter yang paling tinggi perbedaannya adalah panjang umbi, jumlah umbi per tanaman, jumlah umbi per plot, dan hasil umbi.

Eigenvalue yang lebih dari 1 dimiliki oleh F1 - F6 dan dapat menjelaskan $87,31 \%$ dari $100 \%$ proporsi variasi karakter yang terjadi (Tabel 2). Komponen pertama (F1) memiliki variabilitas 34,60\%, komponen kedua (F2) memiliki variabilitas 25,97\%, komponen ketiga (F3) memiliki variabilitas 10,19\%, komponen keempat (F4) memiliki variabilitas 7,68\%, komponen kelima (F5) memiliki variabilitas 5,43\%, dan komponen keenam (F6) memiliki variabilitas 
3,43\%. Karakter-karakter yang dominan diperlihatkan dengan nilai loading factor > 0,5 dapat dilihat pada Tabel 3 .

Biplot respons spesifik karakter pada 48 genotip ubi jalar jingga di lahan tegalan dan lahan sawah disajikan pada Gambar 1. Genotip yang berada di luar elips menandakan genotip tersebut beragam, jika dikombinasikan dengan sektor menunjukkan karakter penciri spesifik untuk genotip di sektor tersebut. Berdasarkan garis pembagi karakter penciri spesifik, maka respon spesifik karakter pada 48 genotip ubi jalar terbagi menjadi lima sektor. Karakter yang berada di ujung poligon adalah karakter penciri spesifik.

Karakter penciri pada sektor I adalah hasil umbi (I), pada sektor ini tidak ada genotip yang beragam. Karakter penciri pada sektor II adalah panjang umbi (A), pada sektor ini tidak ada genotip yang beragam. Karakter penciri pada sektor III adalah bobot 10 umbi (L), pada sektor ini tidak ada genotip yang beragam. Karakter penciri pada sektor VI adalah kandungan pati \% FW (M), pada sektor ini tidak ada genotip yang beragam. Karakter penciri pada sektor $\mathrm{V}$ adalah jumlah umbi per plot (G), pada sektor ini genotip yang beragam ada 17 genotip di lahan kering, yaitu 194 (276), 186 (322), 193 (275), 199 (294), 195 (281), 42 (10), 217 (493), 219 (473), 190 (350), 201 (295), 28 (106), 110 (237), 117 (240), 112 (232), 119 (247), 203 (290), dan 113 (222). Sedangkan di lahan basah tidak ada genotip yang beragam.

Korelasi antar karakter dilihat dari sudut yang dibentuk, jika sudut $<90^{\circ}$ maka berkorelasi positif, jika sudut yang dibentuk $180^{\circ}$ maka berkorelasi negatif. Karakter $\mathrm{G}$ berkorelasi positif dengan I dan berkorelasi negatif dengan A, L, dan M. Karakter A, L, M, dan I berkorelasi positif. Dengan kata lain dapat disimpulkan bahwa jumlah umbi dapat mempengaruhi hasil umbi dan kadar pati $\%$ FW dapat dipengaruhi oleh panjang umbi dan bobot 10 umbi.

Terdapat delapan kelompok genotip berdasarkan respons 18 karakter genotip ubi jalar jingga di lahan tegalan dan lahan sawah (Gambar 2). Kelompok A terdiri dari 1 genotip, yaitu 224 (339). Kelompok B terdiri dari 1 genotip yaitu 194 (276). Kelomok C terdiri dari 1 genotip yaitu 105 (185). Kelompok D terdiri dari 1 genotip yaitu 113 (222). Kelompo E terdiri dari 1 gentotp yaitu 26 (139). Kelompok F terdiri dari 33 genotip, yaitu 186 (322), 190 (350), 201 (295), 193 (275), 217 (493), 219 (473), 101 (159), 195 (281), 189 (329), 272 (632), 253 (452), 108 (163), 106 (192), 262 (399), 20 (124), 119 (247), Ayamurasaki, Kuput, 230 (420), 114 (295), Shiroyutaka, 150 (263), 256 (472), 203 (290), 110 (237), 183 (306), 112 (232), 117 (240), 218 (469), 118 (245), 182 (314), 114 (203), dan 300 (635). Kelompok G terdiri dari 4 genotip, yaitu : 264 (493), 261 (375), 228 (447) dan 252 (481). Kelompok H terdiri dari 6 genotip, yaitu 199 (294), CIA, Rancing, 23 (89), dan 28 (106).

Karakter yang mempunyai jumlah genotip paling banyak adalah kandungan gula reduksi (\%) FW dan hasil kandungan pati (t/ha) yaitu masingmasing 20 genotip, karakter dengan genotip paling sedikit adalah panjang umbi 
(cm) dan jumlah umbi per plot yaitu masing-masing 15 dan 11. Genotip dengan jumlah rata-rata karakter tertingi paling banyak adalah 224 (399b), 42 (10), dan 199 (294) yaitu masing-masing 17, 16, dan 15. Genotip dengan jumlah rata-rata karakter tertinggi paling sedikit adalah 300 (635), 105 (185), dan 118 (245) yaitu masing-masing 0,1 , dan 2.

Respon tanaman ubi jalar dalam menyerap unsur hara dipengaruhi oleh pertumbuhan genetik, tipe tanah, dan zona agroklimatnya (Sharma and Trehan, 2005; Trehan, 2007). Ketiga hal tersebut selalu berhubungan dengan potensi hasil tanaman, jumlah umbi dan ukuran umbi (Trehan \& Grewal, 1990).

\section{KESIMPULAN DAN SARAN}

Ada perbedaan respon karakter pada 43 genotip ubi jalar berdaging jingga di lahan tegalan dan lahan bekas sawah. Karakter yang menjadi penciri spesifik adalah karakter pada sektor $\mathrm{V}$ adalah jumlah umbi per plot $(\mathrm{G})$, pada sektor ini genotip yang beragam ada 17 genotip di lahan tegalan, yaitu 194 (276), 186 (322), 193 (275), 199 (294), 195 (281), 42 (10), 217 (493), 219 (473), 190 (350), 201 (295), 28 (106), 110 (237), 117 (240), 112 (232), 119 (247), 203 (290), dan 113 (222). Sedangkan di lahan bekas sawah tidak ada genotip yang beragam. Genotip dengan jumlah rata-rata karakter tertinggi paling banyak adalah 224 (399b), 42 (10), dan 199 (294) yaitu masing-masing 17, 16, dan 15.

\section{DAFTAR PUSTAKA}

Balitkabi. 2012. Deskripsi Varietas Unggul Kacang-kacangan dan Umbi-umbian. Badan Penelitian dan Pengembangan Pertanian. Kementrian Pertanian.

Brabet, C., D. Reynoso, D. Dufour, C. Mestres, J. Arredondo, and G. Scott. 1998.

Starch content and properties of 106 sweetpotato clones from the world germplasm collection held at CIP, Peru. CIP Progress Report 1997-98: 279-286.

Biro Pusat Statistik. 2014. Tabel Produksi Ubi Jalar Menurut Provinsi 2010 2014. Available at http://www.bps.go.id/tnmn_pgn.php?eng=0 Diakses 10 Februari 2015.

Huang, H.H., G.Q. Lu, and Q.Y. Shu. 2005. Genetic variation in the starch gelatinization characteristics of sweetpotato with high pigment contents. Acta Agronomica Sinica 31(1): 92-96.

Jusuf, M. A., Rahayuningsi, A., and Pambudi, S. 2002. Adaptasi dan Stabilitas Hasil Klon-klon Harapan Ubi Jalar. Jurnal Teknologi Adaptif Tanaman Kacang-Kacangan Dan Umbi-umbian. 
Karuniawan, Agung., B. Waluyo., W. Chandria., H. Maulana, dan S.L. Rahmannisa.2012. Pengelolaan dan Pemanfaatan Plasma Nutfah Ubi Jalar Lokal Jawa Barat. Available at http://www.researchgate.net/publication/248400559_PENGELOLAAN_ DAN_PEMANFAATAN_PLASMA_NUTFAH_UBI_JALAR_LOKAL _JAWA_BARAT. Diakses 12 Maret 2014.

Katayama, K., K. Komae, S. Tamiya, K. Khoyama, M. Nakatani, and K. Komaki. 2006. Studies on the breeding for improving starch properties in sweet potato. JARQ 40(2): 115 - 122 Available at http://www.jircas.affrc.go.jp.

Onwueme, I. C., and Sinha, T. O. 1991. Field crop production in Tropical Africa, principles and practice (pp. 267-275). CTA (Technical Centre for Agriculture and Rural Cooperation) Ede, The Netherlands. Available at www.ccsenet.org/journal/index.php/jas/article/download/25233/16914.

Diakses 12 Maret 2014.

Palmer,J.K. 1982. Carbohydrate in Sweet Potato. In R.L.Villareal and T.D Griggs (Eds.).The First Int. Symposium Asian Vegetable. Res. Dev. Center. Shanhua.

Petersen, Roger G. 1994. Agricultural Field Experiments Design and Analysis. Marcel Dekker Inc, New York.

Puspita, Lani., E. Ratnawati., I N.N. Suryadiputra., A. A. Meutia. 2005. Lahan Basah Buatan di Indonesia. Bogor, Wetland International Indonesia Programme.

Notohadiprawiro, Tejoyuwono. 2006. Pertanian Lahan Kering di Indonesia; Potensi, Prospek, Kendala, dan Pengembangannya. Ilmu Tanah Universitas Gadjah Mada.

Ukom, A. N., Ojimelukwe, P. C., and Okpara, D. A. 2009. Nutrient composition of selected sweet potato [Ipomoea batatas (L.) Lam] varieties as influenced by different levels of nitrogen fertilizer application. Pakistan Journal of Nutrition, 8(11), 1791-1795. Available at http://dx.doi.org/10.3923/pjn.2009.1791.1795. Diakses 12 Maret 2014.

Yan W, Kang MS (2003) GGE-Biplot Analysis: A Graphical Tool for Breeders. Geneticists and Agronomists. CRD Press, Boca Raton.

Zanetta, Chindy Ulima. 2014. Stabilitas dan Adaptabilitas Hasil dan Komponen Hasil Genotip Potensial Kedelai Hitam di Pulau Jawa. Tesis. Fakultas Pertanian. Universitas Padjadjaran. 
Tabel 1. Rata-rata penampilan karakter hasil dan komponen hasil 48 genotip ubi jalar berdaging umbi hingga pada lahan tegalan dan lahan sawah

\begin{tabular}{|c|c|c|c|c|c|}
\hline Sample & Min. & Mak. & Rata-rata & Standar deviasi & SE Rata-rata \\
\hline K_Panjang umbi (cm) & 11.40 & 27.60 & 18.09 & 3.97 & 0.57 \\
\hline K_Diameter umbi $(\mathrm{cm})$ & 1.16 & 14.14 & 5.35 & 1.93 & 0.28 \\
\hline K_Jumlah umbi pertanaman & 1.00 & 10.00 & 3.33 & 1.55 & 0.22 \\
\hline K_Bobot umbi pertanaman (kg) & 0.06 & 1.16 & 0.43 & 0.21 & 0.03 \\
\hline K_Jumlah umbi ekonomis pertanaman (kg) & 0.40 & 2.60 & 1.47 & 0.52 & 0.07 \\
\hline K_Bobot umbi ekonomis pertanaman (kg) & 0.04 & 1.02 & 0.35 & 0.20 & 0.03 \\
\hline K_Jumlah umbi perplot & 25.00 & 250.00 & 83.35 & 38.67 & 5.58 \\
\hline K_Bobot umbi perplot (kg) & 1.50 & 29.00 & 10.64 & 5.13 & 0.74 \\
\hline K_Hasil umbi (t/ha) & 3.00 & 58.00 & 21.28 & 10.27 & 1.48 \\
\hline K_Bobot 10 umbi $(\mathrm{kg})$ & 0.60 & 11.60 & 4.26 & 2.05 & 0.30 \\
\hline K_Kandungan berat kering $\%$ FW & 26.20 & 36.80 & 30.75 & 1.91 & 0.28 \\
\hline $\mathrm{K} \_$Kandungan air $(\%) \mathrm{FW}$ & 63.20 & 73.80 & 69.25 & 1.91 & 0.28 \\
\hline K_Kandungan pati (\%) FW & 9.21 & 17.09 & 12.62 & 1.75 & 0.25 \\
\hline K_Kandungan gula reduksi (\%) FW & 2.49 & 4.40 & 3.70 & 0.39 & 0.06 \\
\hline K_Hasil Kandungan berat kering (t/ha) & 1.01 & 17.10 & 6.48 & 2.99 & 0.43 \\
\hline K_Hasil kandungan air (t/ha) & 1.99 & 40.90 & 14.79 & 7.31 & 1.05 \\
\hline K_Hasil kandungan pati (t/ha) & 0.51 & 6.13 & 2.64 & 1.20 & 0.17 \\
\hline K_Hasil kandungan gula reduksi (t/ha) & 0.12 & 2.31 & 0.79 & 0.40 & 0.06 \\
\hline B_Panjang umbi $(\mathrm{cm})$ & 2.62 & 28.40 & 17.88 & 4.46 & 0.64 \\
\hline B_Diameter umbi $(\mathrm{cm})$ & 1.16 & 9.44 & 5.19 & 1.35 & 0.20 \\
\hline B_Jumlah umbi pertanaman & 0.40 & 5.20 & 2.71 & 1.15 & 0.17 \\
\hline B_Bobot umbi pertanaman (kg) & 0.02 & 1.04 & 0.38 & 0.23 & 0.03 \\
\hline B_Jumlah umbi ekonomis pertanaman $(\mathrm{kg})$ & 0.40 & 2.80 & 1.35 & 0.63 & 0.09 \\
\hline
\end{tabular}




Sample

B_Bobot umbi ekonomis pertanaman $(\mathrm{kg})$

B_Jumlah umbi perplot

B_Bobot umbi perplot $(\mathrm{kg})$

B_Hasil umbi (t/ha)

B_Bobot 10 umbi $(\mathrm{kg})$

B_Kandungan berat kering \% FW

B_Kandungan air (\%) FW

B_Kandungan pati (\%) FW

B_Kandungan gula reduksi (\%) FW

B_Hasil Kandungan berat kering (t/ha)

B_Hasil kandungan air (t/ha)

B_Hasil kandungan pati (t/ha)

B_Hasil kandungan gula reduksi (t/ha)

Keterangan : K Lahan Kering, B Lahan Basah

\begin{tabular}{rrrrr}
\multicolumn{1}{l}{ Min. } & Mak. & Rata-rata & Standar deviasi & SE Rata-rata \\
0.02 & 0.92 & 0.31 & 0.21 & 0.03 \\
9.00 & 72.00 & 32.55 & 15.19 & 2.19 \\
0.20 & 16.40 & 4.87 & 3.19 & 0.46 \\
0.40 & 32.80 & 9.74 & 6.37 & 0.92 \\
0.20 & 10.40 & 3.78 & 2.27 & 0.33 \\
26.65 & 33.74 & 29.81 & 1.65 & 0.24 \\
66.26 & 73.35 & 70.19 & 1.65 & 0.24 \\
9.35 & 16.04 & 12.45 & 1.52 & 0.22 \\
2.68 & 4.61 & 3.60 & 0.46 & 0.07 \\
0.11 & 10.57 & 2.92 & 1.98 & 0.29 \\
0.29 & 22.23 & 6.82 & 4.41 & 0.64 \\
0.05 & 4.78 & 1.23 & 0.86 & 0.12 \\
0.01 & 1.38 & 0.36 & 0.25 & 0.04
\end{tabular}

Tabel 2 . Eigenvalues 18 Karakter pada 48 genotip ubi jalar berdaging umbi jingga di lahan kering dan lahan sawah

\begin{tabular}{lrrrrrrr}
\hline & F1 & F2 & F3 & F4 & \multicolumn{1}{r}{ F5 } & F6 & F7 \\
\hline Eigenvalue & 12.46 & 9.35 & 3.67 & 2.77 & 1.95 & 1.24 & 0.90 \\
Variabilitas (\%) & 34.60 & 25.97 & 10.19 & 7.68 & 5.43 & 3.43 & 2.50 \\
Kumulatif \% & 34.60 & 60.57 & 70.76 & 78.45 & 83.87 & 87.31 & 89.80 \\
\hline
\end{tabular}


Tabel 3. Nilai loading factor enam komponen utama pertama 18 karakter pada 48 genotip ubi jalar berdaging umbi jingga yang ditanam di lahan tegalan dan lahan sawah

\begin{tabular}{|c|c|c|c|c|c|c|}
\hline & F1 & $\mathrm{F} 2$ & $\mathrm{~F} 3$ & $\mathrm{~F} 4$ & F5 & F6 \\
\hline K_Panjang umbi (cm) & 0.421 & 0.456 & -0.189 & -0.011 & -0.222 & 0.355 \\
\hline K_Diameter umbi $(\mathrm{cm})$ & 0.484 & 0.173 & -0.202 & 0.485 & 0.263 & -0.057 \\
\hline K_Jumlah umbi pertanaman & 0.073 & 0.229 & 0.511 & -0.645 & 0.307 & 0.371 \\
\hline K_Bobot umbi pertanaman (kg) & 0.636 & 0.764 & 0.042 & 0.011 & -0.042 & -0.043 \\
\hline K_Jumlah umbi ekonomis pertanaman (kg) & 0.578 & 0.487 & 0.293 & -0.080 & 0.175 & -0.311 \\
\hline K_Bobot umbi ekonomis pertanaman (kg) & 0.687 & 0.673 & -0.040 & 0.145 & -0.094 & -0.143 \\
\hline K_Jumlah umbi perplot & 0.073 & 0.229 & 0.511 & -0.645 & 0.307 & 0.371 \\
\hline K_Bobot umbi perplot $(\mathrm{kg})$ & 0.636 & 0.764 & 0.042 & 0.011 & -0.042 & -0.043 \\
\hline K_Hasil umbi (t/ha) & 0.636 & 0.764 & 0.042 & 0.011 & -0.042 & -0.043 \\
\hline K_Bobot 10 umbi $(\mathrm{kg})$ & 0.636 & 0.764 & 0.042 & 0.011 & -0.042 & -0.043 \\
\hline K_Kandungan berat kering \% FW & -0.350 & -0.192 & 0.641 & 0.009 & -0.591 & 0.000 \\
\hline K_Kandungan air (\%) FW & 0.350 & 0.192 & -0.641 & -0.009 & 0.591 & 0.000 \\
\hline K_Kandungan pati (\%) FW & -0.367 & -0.079 & 0.604 & 0.019 & 0.033 & -0.329 \\
\hline K_Kandungan gula reduksi (\%) FW & -0.278 & 0.123 & 0.636 & 0.030 & -0.488 & 0.034 \\
\hline K_Hasil Kandungan berat kering (t/ha) & 0.627 & 0.755 & 0.124 & 0.017 & -0.099 & -0.038 \\
\hline K_Hasil kandungan air (t/ha) & 0.637 & 0.765 & 0.008 & 0.008 & -0.018 & -0.045 \\
\hline K_Hasil kandungan pati (t/ha) & 0.603 & 0.731 & 0.231 & 0.015 & 0.001 & -0.115 \\
\hline K_Hasil kandungan gula reduksi (t/ha) & 0.583 & 0.764 & 0.166 & 0.021 & -0.138 & -0.019 \\
\hline B_Panjang umbi $(\mathrm{cm})$ & 0.757 & -0.093 & -0.172 & -0.036 & -0.146 & 0.486 \\
\hline B_Diameter umbi $(\mathrm{cm})$ & 0.677 & -0.118 & -0.235 & -0.086 & -0.341 & 0.166 \\
\hline B_Jumlah umbi pertanaman & 0.450 & -0.348 & 0.485 & -0.219 & 0.458 & -0.049 \\
\hline B_Bobot umbi pertanaman $(\mathrm{kg})$ & 0.806 & -0.495 & 0.009 & 0.009 & -0.047 & 0.119 \\
\hline B_Jumlah umbi ekonomis pertanaman (kg) & 0.631 & -0.544 & 0.103 & 0.014 & 0.073 & -0.064 \\
\hline
\end{tabular}




\begin{tabular}{|c|c|c|c|c|c|c|}
\hline & $\mathrm{F} 1$ & $\mathrm{~F} 2$ & F3 & F4 & F5 & F6 \\
\hline B_Bobot umbi ekonomis pertanaman (kg) & 0.780 & -0.461 & -0.115 & 0.032 & -0.147 & 0.149 \\
\hline B_Jumlah umbi perplot & 0.577 & -0.497 & 0.260 & -0.239 & 0.228 & -0.279 \\
\hline B_Bobot umbi perplot (kg) & 0.769 & -0.573 & -0.063 & -0.158 & -0.103 & -0.111 \\
\hline B_Hasil umbi (t/ha) & 0.769 & -0.573 & -0.063 & -0.158 & -0.103 & -0.111 \\
\hline B_Bobot 10 umbi $(\mathrm{kg})$ & 0.806 & -0.495 & 0.009 & 0.009 & -0.047 & 0.119 \\
\hline B_Kandungan berat kering $\% \mathrm{FW}$ & 0.321 & -0.212 & 0.476 & 0.656 & 0.264 & 0.208 \\
\hline B_Kandungan air (\%) FW & -0.321 & 0.212 & -0.476 & -0.656 & -0.264 & -0.208 \\
\hline B_Kandungan pati (\%) FW & 0.167 & -0.183 & 0.610 & 0.133 & 0.076 & -0.044 \\
\hline B_Kandungan gula reduksi (\%) FW & 0.191 & -0.271 & 0.184 & 0.753 & 0.031 & 0.159 \\
\hline B_Hasil Kandungan berat kering (t/ha) & 0.772 & -0.586 & -0.011 & -0.098 & -0.085 & -0.096 \\
\hline B_Hasil kandungan air (t/ha) & 0.765 & -0.565 & -0.087 & -0.184 & -0.111 & -0.118 \\
\hline B_Hasil kandungan pati (t/ha) & 0.758 & -0.586 & 0.046 & -0.101 & -0.059 & -0.115 \\
\hline B_Hasil kandungan gula reduksi (t/ha) & 0.752 & -0.600 & 0.011 & -0.012 & -0.105 & -0.088 \\
\hline
\end{tabular}


Tabel 4. Penampilan rata-rata karakter hasil dan komponen hasil serta fisiko-kimia 48 genotip ubi jalar jingga pada lahan tegalan dan lahan sawah

\begin{tabular}{|c|c|c|c|c|c|c|c|c|c|c|c|c|c|c|c|c|c|c|}
\hline Genotip & 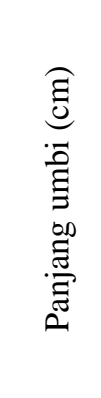 & 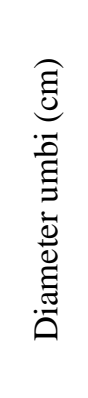 & 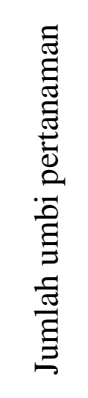 & 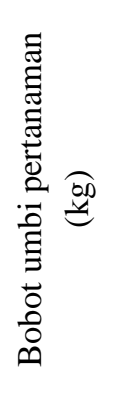 & 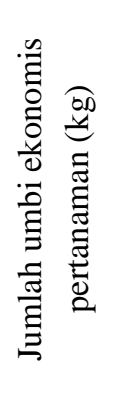 & 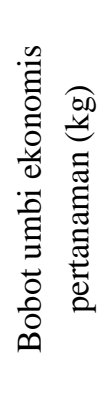 & 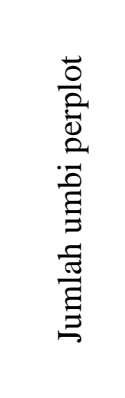 & 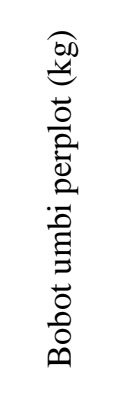 & 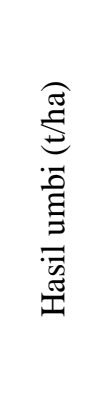 & 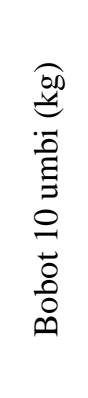 & 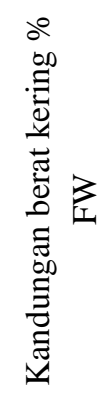 & 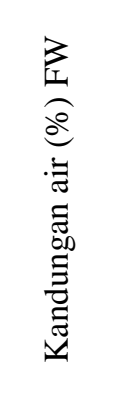 & 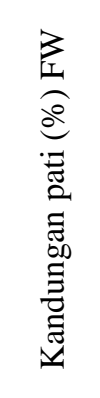 & 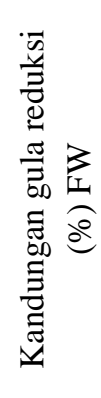 & 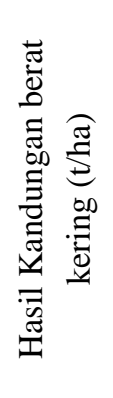 & 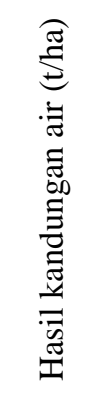 & 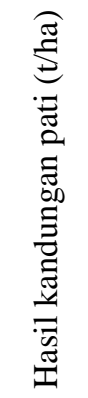 & 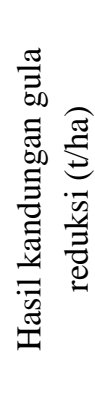 \\
\hline $101(159)$ & 16.04 & 5.13 & 1.90 & 0.33 & 1.20 & 0.29 & 33.00 & $9.05+$ & $\begin{array}{r}18.10 \\
+\end{array}$ & 3.30 & $\begin{array}{r}30.72 \\
+\end{array}$ & 69.28 & 12.41 & $\begin{array}{r}3.79 \\
+\end{array}$ & $\begin{array}{r}5.57 \\
+\end{array}$ & $\begin{array}{r}12.53 \\
+\end{array}$ & $\begin{array}{r}2.39 \\
+\end{array}$ & $\begin{array}{r}0.70 \\
+\end{array}$ \\
\hline 105 (185) & 7.01 & 1.16 & 0.70 & 0.04 & 0.40 & 0.03 & 18.50 & 0.85 & 1.70 & 0.40 & 30.48 & 69.52 & $\begin{array}{r}14.47 \\
+\end{array}$ & 3.55 & 0.56 & 1.14 & 0.28 & 0.07 \\
\hline $106(192)$ & 17.45 & 5.61 & 2.10 & 0.31 & 1.40 & 0.26 & 42.00 & 6.00 & 12.00 & 3.10 & 29.32 & $\begin{array}{r}70.68 \\
+\end{array}$ & 12.72 & 3.65 & 3.62 & 8.38 & 1.60 & 0.43 \\
\hline $108(163)$ & 18.85 & 4.17 & 2.70 & 0.21 & 1.20 & 0.18 & 47.00 & 4.15 & 8.30 & 2.10 & $\begin{array}{r}33.45 \\
+\end{array}$ & 66.55 & $\begin{array}{r}13.31 \\
+\end{array}$ & $\begin{array}{r}4.13 \\
+\end{array}$ & 2.83 & 5.47 & 1.10 & 0.35 \\
\hline $110(237)$ & 15.52 & 5.33 & $\begin{array}{r}3.50 \\
+\end{array}$ & 0.31 & 1.30 & 0.23 & $74.00+$ & 6.90 & 13.80 & 3.10 & $\begin{array}{r}31.10 \\
+\end{array}$ & 68.90 & $\begin{array}{r}14.76 \\
+\end{array}$ & $\begin{array}{r}3.81 \\
+\end{array}$ & 4.34 & 9.46 & 2.03 & 0.54 \\
\hline $112(232)$ & 17.75 & 3.78 & $\begin{array}{r}4.70 \\
+\end{array}$ & 0.27 & 1.30 & 0.16 & $82.50+$ & 5.60 & 11.20 & 2.70 & 29.83 & $\begin{array}{r}70.17 \\
+\end{array}$ & $\begin{array}{r}13.61 \\
+\end{array}$ & $\begin{array}{r}3.86 \\
+\end{array}$ & 3.32 & 7.88 & 1.52 & 0.44 \\
\hline $113(222)$ & 17.55 & 3.66 & $\begin{array}{r}7.00 \\
+\end{array}$ & 0.29 & 0.80 & 0.10 & $\begin{array}{r}141.00 \\
+\end{array}$ & 5.60 & 11.20 & 2.90 & 30.30 & 69.70 & $\begin{array}{r}13.30 \\
+\end{array}$ & 3.29 & 3.54 & 7.66 & 1.56 & 0.40 \\
\hline $114(203)$ & 14.05 & 3.03 & 1.90 & 0.11 & 1.10 & 0.09 & 37.00 & 2.15 & 4.30 & 1.10 & $\begin{array}{r}31.37 \\
+\end{array}$ & 68.63 & $\begin{array}{r}13.16 \\
+\end{array}$ & $\begin{array}{r}4.08 \\
+\end{array}$ & 1.43 & 2.87 & 0.57 & 0.19 \\
\hline $117(240)$ & 15.95 & 4.41 & $\begin{array}{r}5.40 \\
+\end{array}$ & 0.32 & 1.50 & 0.20 & $91.00+$ & 6.80 & 13.60 & 3.20 & 29.42 & $\begin{array}{r}70.58 \\
+\end{array}$ & 12.88 & 3.32 & 4.07 & 9.53 & 1.76 & 0.48 \\
\hline
\end{tabular}




\begin{tabular}{|c|c|c|c|c|c|c|c|c|c|c|c|c|c|c|c|c|c|c|}
\hline Genotip & 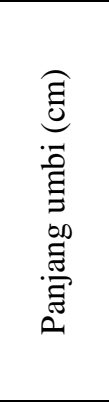 & 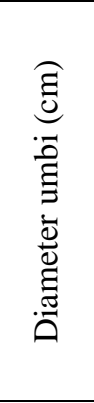 & 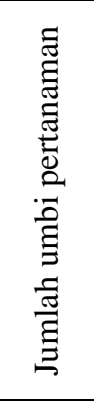 & 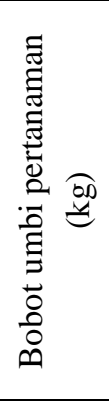 & 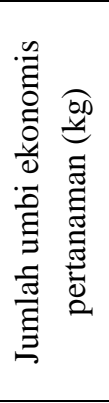 & 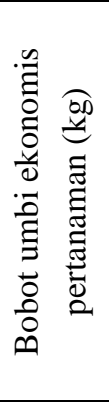 & 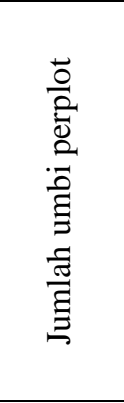 & 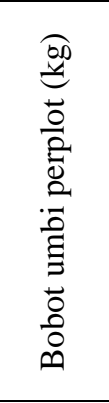 & 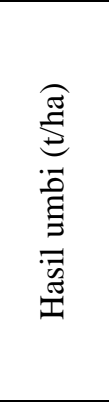 & 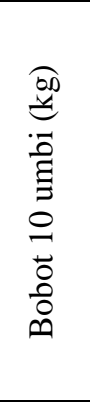 & 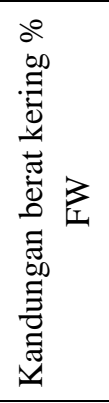 & 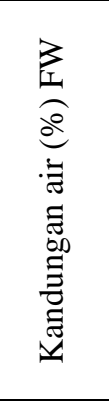 & 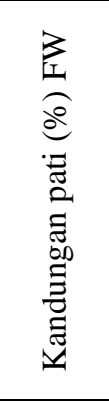 & 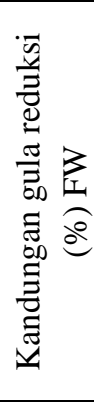 & 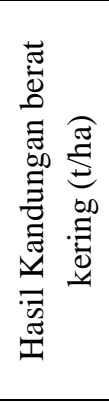 & 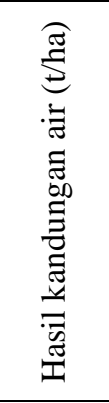 & 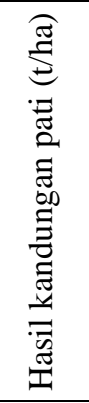 & 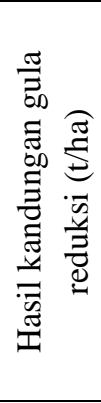 \\
\hline 118 (245) & 14.01 & 4.15 & 2.60 & 0.23 & 1.30 & 0.18 & 44.50 & 3.65 & 7.30 & 2.30 & $\begin{array}{r}31.13 \\
+\end{array}$ & 68.87 & 12.75 & & 2.23 & 5.07 & 1.02 & 0.28 \\
\hline 119 (247) & 15.02 & 4.74 & $\begin{array}{r}4.00 \\
+\end{array}$ & 0.39 & $\begin{array}{r}1.80 \\
+\end{array}$ & 0.30 & $76.50+$ & 6.65 & 13.30 & 3.90 & $\begin{array}{r}31.74 \\
+\end{array}$ & 68.26 & 12.51 & $\begin{array}{r}3.91 \\
+\end{array}$ & 4.24 & 9.06 & 1.70 & 0.52 \\
\hline 144 (295) & 13.35 & 5.21 & 2.50 & 0.28 & 1.00 & 0.21 & 42.50 & 6.25 & 12.50 & 2.80 & $\begin{array}{r}31.19 \\
+\end{array}$ & 68.81 & $\begin{array}{r}14.09 \\
+\end{array}$ & $\begin{array}{r}4.09 \\
+\end{array}$ & 39 & 8.58 & 1.76 & 0.51 \\
\hline $150(263)$ & 18.04 & $\begin{array}{r}6.05 \\
+\end{array}$ & 2.20 & $\begin{array}{r}0.48 \\
+\end{array}$ & 1.10 & $\begin{array}{r}0.42 \\
+\end{array}$ & 55.00 & 8.25 & 16.50 & $\begin{array}{r}4.80 \\
+\end{array}$ & 30.36 & 69.64 & $\begin{array}{r}13.14 \\
+\end{array}$ & $\begin{array}{r}3.88 \\
+\end{array}$ & 5.16 & 11.34 & $\begin{array}{r}2.16 \\
+\end{array}$ & $\begin{array}{r}0.65 \\
+\end{array}$ \\
\hline $182(314$ & 15.95 & 4.93 & 2.10 & 0.26 & 1.20 & 0.23 & 39.50 & 4.31 & 8.60 & 2.60 & $\begin{array}{r}30.81 \\
+\end{array}$ & 69.19 & 12.71 & $\begin{array}{r}3.77 \\
+\end{array}$ & 2.64 & 5.96 & 1.16 & 0.32 \\
\hline $183(306)$ & $\begin{array}{r}19.05 \\
+\end{array}$ & 4.32 & 2.70 & 0.28 & 1.00 & 0.20 & 47.50 & 6.40 & 12.80 & 2.80 & $\begin{array}{r}30.77 \\
+\end{array}$ & 69.23 & $\begin{array}{r}13.45 \\
+\end{array}$ & 3.51 & 4.02 & 8.78 & 1.66 & 0.47 \\
\hline $186(322)$ & $\begin{array}{r}24.30 \\
+\end{array}$ & $\begin{array}{r}5.83 \\
+\end{array}$ & 2.90 & $\begin{array}{r}0.64 \\
+\end{array}$ & $\begin{array}{r}2.00 \\
+\end{array}$ & $\begin{array}{r}0.58 \\
+\end{array}$ & 59.50 & + & $\begin{array}{r}28.10 \\
+\end{array}$ & $\begin{array}{r}6.40 \\
+\end{array}$ & 27.05 & $\begin{array}{r}72.95 \\
+\end{array}$ & 11.60 & 2.95 & $\begin{array}{r}7.55 \\
+\end{array}$ & $\begin{array}{r}20.55 \\
+\end{array}$ & $\begin{array}{r}3.21 \\
+\end{array}$ & $\begin{array}{r}0.84 \\
+\end{array}$ \\
\hline & $\begin{array}{r}20.30 \\
+\end{array}$ & 5.44 & 2.40 & 0.35 & 1.20 & 0.30 & 39.00 & 7.35 & 14.70 & 3.50 & 29.74 & & & 3.22 & 4.20 & 10.50 & 1.54 & 0.38 \\
\hline $190(350)$ & $\begin{array}{r}20.00 \\
+\end{array}$ & 4.62 & $\begin{array}{r}4.60 \\
+\end{array}$ & $\begin{array}{r}0.48 \\
+\end{array}$ & $\begin{array}{r}1.60 \\
+\end{array}$ & 0.33 & $90.50+$ & $\begin{array}{r}10.90 \\
+\end{array}$ & $\begin{array}{r}21.80 \\
+\end{array}$ & $\begin{array}{r}4.80 \\
+\end{array}$ & 29.10 & $\begin{array}{r}70.90 \\
+\end{array}$ & & 3.52 & $\begin{array}{r}6.47 \\
+\end{array}$ & $\begin{array}{r}15.33 \\
+\end{array}$ & $\begin{array}{r}2.71 \\
+\end{array}$ & $\begin{array}{r}0.83 \\
+\end{array}$ \\
\hline $193(275)$ & 17.65 & $\begin{array}{r}5.90 \\
+\end{array}$ & 2.00 & $\begin{array}{r}0.51 \\
+\end{array}$ & 1.40 & $\begin{array}{r}0.49 \\
+\end{array}$ & 42.00 & $\begin{array}{r}11.15 \\
+\end{array}$ & $\begin{array}{r}22.30 \\
+\end{array}$ & $\begin{array}{r}5.10 \\
+\end{array}$ & 28.01 & $\begin{array}{r}71.99 \\
+\end{array}$ & 11.52 & 3.37 & $\begin{array}{r}6.44 \\
+\end{array}$ & $\begin{array}{r}15.86 \\
+\end{array}$ & $\begin{array}{r}2.59 \\
+\end{array}$ & $\begin{array}{r}0.85 \\
+\end{array}$ \\
\hline 194 (276) & 25.30 & 7.56 & 3.40 & 0.81 & 1.50 & 0.72 & 64.00 & 15.75 & 31.50 & 8.10 & 30.12 & 69.88 & 11.19 & 3.87 & 9.32 & 22.18 & 3.36 & 1.25 \\
\hline
\end{tabular}




\begin{tabular}{|c|c|c|c|c|c|c|c|c|c|c|c|c|c|c|c|c|c|c|}
\hline Genotip & 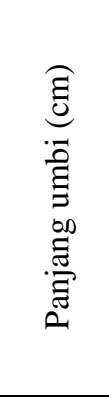 & 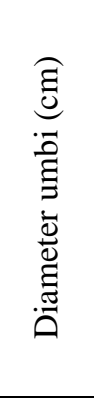 & 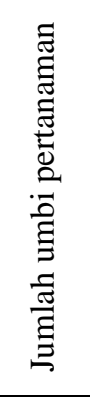 & 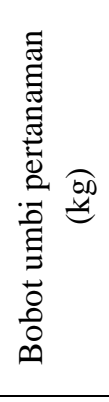 & 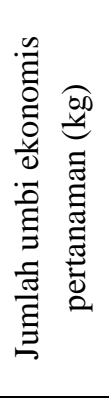 & 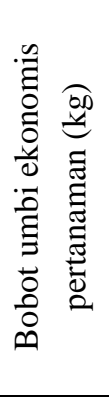 & 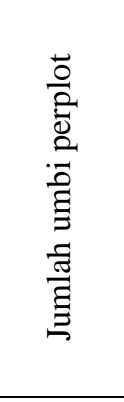 & 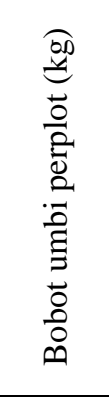 & 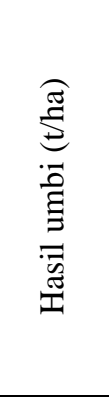 & 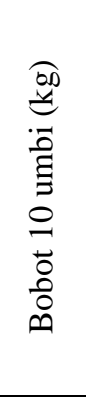 & 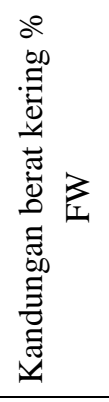 & 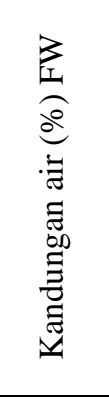 & 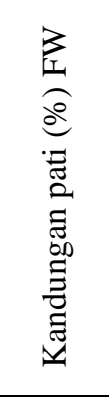 & 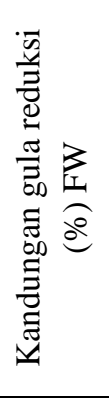 & 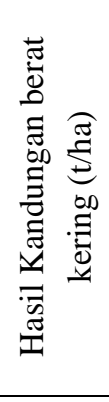 & 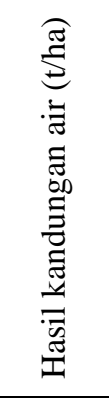 & 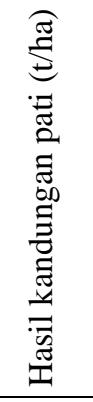 & 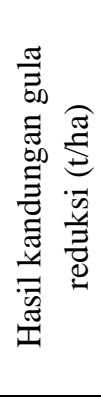 \\
\hline & + & + & 1 & + & & + & & & & & & & & & & & & + \\
\hline 195 (281) & 17.60 & $\begin{array}{r}6.17 \\
+\end{array}$ & 3.30 & $\begin{array}{r}0.47 \\
+\end{array}$ & $\begin{array}{r}1.70 \\
+\end{array}$ & $\begin{array}{r}0.41 \\
+\end{array}$ & 59.00 & $.50+$ & $\begin{array}{r}19.00 \\
+\end{array}$ & $\begin{array}{r}4.70 \\
+\end{array}$ & 30.36 & 69.64 & & 3.64 & $\begin{array}{r}5.63 \\
+\end{array}$ & $\begin{array}{r}3.37 \\
+\end{array}$ & $\begin{array}{r}.38 \\
+\end{array}$ & $\begin{array}{r}0.68 \\
+\end{array}$ \\
\hline 199 (294) & $\begin{array}{r}23.85 \\
+\end{array}$ & $\begin{array}{r}6.52 \\
+\end{array}$ & 3.20 & $\begin{array}{r}0.83 \\
+\end{array}$ & $\begin{array}{r}2.00 \\
+\end{array}$ & $\begin{array}{r}0.77 \\
+\end{array}$ & 57.50 & $\begin{array}{r}13.35 \\
+\end{array}$ & $\begin{array}{r}26.70 \\
+\end{array}$ & $\begin{array}{r}8.30 \\
+\end{array}$ & $\begin{array}{r}31.67 \\
+\end{array}$ & 68.33 & $\begin{array}{r}13.43 \\
+\end{array}$ & $\begin{array}{r}4.02 \\
+\end{array}$ & $\begin{array}{r}8.22 \\
+\end{array}$ & $\begin{array}{r}18.48 \\
+\end{array}$ & $\begin{array}{r}3.59 \\
+\end{array}$ & $\begin{array}{r}1.06 \\
+\end{array}$ \\
\hline 20 (124) & 16.70 & 4.19 & $\begin{array}{r}3.90 \\
+\end{array}$ & $\begin{array}{r}0.46 \\
+\end{array}$ & $\begin{array}{r}1.90 \\
+\end{array}$ & 0.34 & $71.50+$ & 7.30 & 14.60 & $\begin{array}{r}4.60 \\
+\end{array}$ & $\begin{array}{r}30.96 \\
+\end{array}$ & 69.04 & 12.38 & 3.48 & 4.52 & 10.08 & 1.84 & 0.51 \\
\hline 201 (295) & $\begin{array}{r}21.08 \\
+\end{array}$ & 4.99 & 3.30 & 0.43 & $\begin{array}{r}1.60 \\
+\end{array}$ & 0.35 & $78.00+$ & + & $\begin{array}{r}20.15 \\
+\end{array}$ & 4.25 & $\begin{array}{r}31.07 \\
+\end{array}$ & 68.93 & 12.13 & $\begin{array}{r}3.94 \\
+\end{array}$ & $\begin{array}{r}6.36 \\
+\end{array}$ & $\begin{array}{r}13.79 \\
+\end{array}$ & $\begin{array}{r}2.40 \\
+\end{array}$ & $\begin{array}{r}0.81 \\
+\end{array}$ \\
\hline 203 (290) & 14.00 & 4.12 & $\begin{array}{r}4.20 \\
+\end{array}$ & 0.22 & 0.70 & 0.09 & $81.50+$ & 4.30 & 8.60 & 2.20 & 30.45 & 69.55 & 11.80 & $\begin{array}{r}3.75 \\
+\end{array}$ & 2.62 & 5.98 & 0.94 & 0.33 \\
\hline $217(493)$ & 18.00 & $\begin{array}{r}6.10 \\
+\end{array}$ & 2.30 & 0.42 & 1.20 & $\begin{array}{r}0.38 \\
+\end{array}$ & 46.50 & $\begin{array}{r}11.10 \\
+\end{array}$ & $\begin{array}{r}22.20 \\
+\end{array}$ & 4.20 & 29.53 & $\begin{array}{r}70.47 \\
+\end{array}$ & 10.98 & 3.51 & $\begin{array}{r}6.67 \\
+\end{array}$ & $\begin{array}{r}15.53 \\
+\end{array}$ & $\begin{array}{r}2.31 \\
+\end{array}$ & $\begin{array}{r}0.81 \\
+\end{array}$ \\
\hline & 1.95 & 5.21 & & 0.25 & 0.70 & 0.19 & & 3.95 & 7.90 & 2.50 & 29.59 & $\begin{array}{r}70.41 \\
+\end{array}$ & & 3.42 & 2.33 & 5.57 & 1.05 & 0.28 \\
\hline $219(473)$ & $\begin{array}{r}24.24 \\
+\end{array}$ & $\begin{array}{r}6.22 \\
+\end{array}$ & 1.90 & $\begin{array}{r}0.58 \\
+\end{array}$ & $\begin{array}{r}1.70 \\
+\end{array}$ & $\begin{array}{r}0.57 \\
+\end{array}$ & 42.50 & $\begin{array}{r}10.85 \\
+\end{array}$ & $\begin{array}{r}21.70 \\
+\end{array}$ & $\begin{array}{r}5.80 \\
+\end{array}$ & 29.92 & 70.08 & & 3.55 & $\begin{array}{r}6.57 \\
+\end{array}$ & $\begin{array}{r}15.13 \\
+\end{array}$ & $\begin{array}{r}2.45 \\
+\end{array}$ & $\begin{array}{r}0.79 \\
+\end{array}$ \\
\hline 224 (399) & $\begin{array}{r}19.82 \\
+\end{array}$ & $\begin{array}{r}6.13 \\
+\end{array}$ & $\begin{array}{r}3.90 \\
+\end{array}$ & $\begin{array}{r}0.64 \\
+\end{array}$ & $\begin{array}{r}2.00 \\
+\end{array}$ & $\begin{array}{r}0.59 \\
+\end{array}$ & $73.50+$ & $\begin{array}{r}11.20 \\
+\end{array}$ & $\begin{array}{r}22.40 \\
+\end{array}$ & $\begin{array}{r}6.40 \\
+\end{array}$ & $\begin{array}{r}30.84 \\
+\end{array}$ & 69.16 & $\begin{array}{r}12.92 \\
+\end{array}$ & $\begin{array}{r}3.93 \\
+\end{array}$ & $\begin{array}{r}7.05 \\
+\end{array}$ & $\begin{array}{r}15.35 \\
+\end{array}$ & $\begin{array}{r}3.07 \\
+\end{array}$ & $\begin{array}{r}0.91 \\
+\end{array}$ \\
\hline $228(447)$ & $\begin{array}{r}24.70 \\
+\end{array}$ & 4.80 & 3.10 & $\begin{array}{r}0.48 \\
+\end{array}$ & 1.50 & $\begin{array}{r}0.43 \\
+\end{array}$ & & 7.70 & 15.40 & $\begin{array}{r}4.80 \\
+\end{array}$ & $\begin{array}{r}30.78 \\
+\end{array}$ & 69.22 & 11.56 & 3.46 & 4.67 & 10.73 & 1.81 & 0.52 \\
\hline
\end{tabular}




\begin{tabular}{|c|c|c|c|c|c|c|c|c|c|c|c|c|c|c|c|c|c|c|}
\hline Genotip & 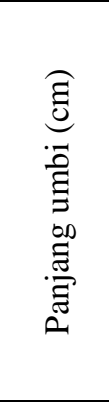 & 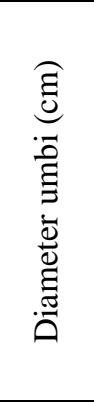 & 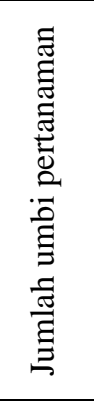 & 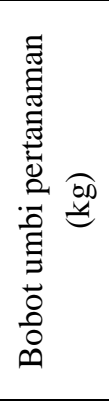 & 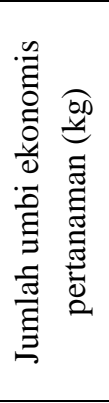 & 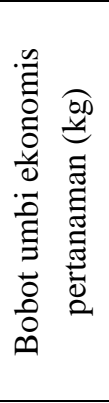 & 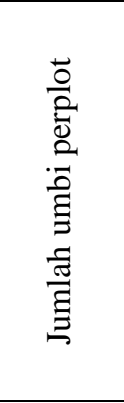 & 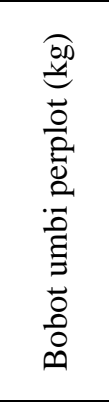 & 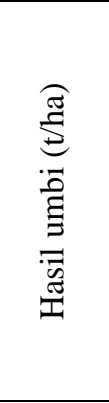 & 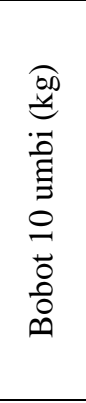 & 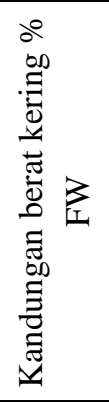 & 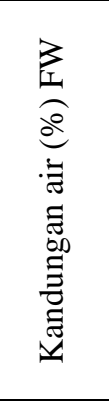 & 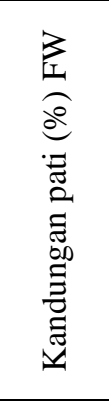 & 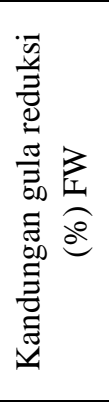 & 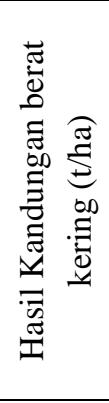 & 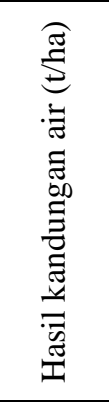 & 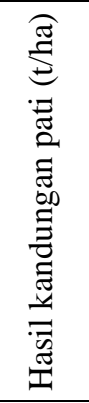 & 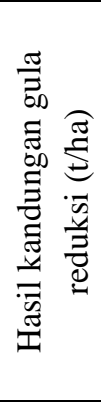 \\
\hline $23(89)$ & 16.21 & 4.81 & $\begin{array}{r}4.50 \\
+\end{array}$ & $\begin{array}{r}0.53 \\
+\end{array}$ & $\begin{array}{r}1.70 \\
+\end{array}$ & 0.34 & $77.50+$ & 8.35 & 16.70 & $\begin{array}{r}5.30 \\
+\end{array}$ & $\begin{array}{r}33.72 \\
+\end{array}$ & 66.28 & $\begin{array}{r}15.63 \\
+\end{array}$ & $\begin{array}{r}3.93 \\
+\end{array}$ & $\begin{array}{r}5.66 \\
+\end{array}$ & 11.04 & $\begin{array}{r}2.59 \\
+\end{array}$ & $\begin{array}{r}0.65 \\
+\end{array}$ \\
\hline $230(420)$ & 18.90 & 5.61 & 2.10 & 0.38 & 1.30 & 0.32 & 44.00 & 7.30 & 14.60 & 3.80 & 30.42 & 69.58 & $\begin{array}{r}12.98 \\
+\end{array}$ & 3.69 & 4.45 & 10.15 & 1.90 & 0.54 \\
\hline $252(481)$ & $\begin{array}{r}19.45 \\
+\end{array}$ & $\begin{array}{r}6.14 \\
+\end{array}$ & 2.70 & $\begin{array}{r}0.57 \\
+\end{array}$ & $\begin{array}{r}1.90 \\
+\end{array}$ & $\begin{array}{r}0.53 \\
+\end{array}$ & 50.00 & $8.75+$ & $\begin{array}{r}17.50 \\
+\end{array}$ & $\begin{array}{r}5.70 \\
+\end{array}$ & 30.51 & 69.49 & 12.86 & 3.73 & $\begin{array}{r}5.34 \\
+\end{array}$ & $\begin{array}{r}12.16 \\
+\end{array}$ & $\begin{array}{r}2.25 \\
+\end{array}$ & $\begin{array}{r}0.65 \\
+\end{array}$ \\
\hline 253 & 18.75 & 5.34 & 3.20 & 0.34 & 1.30 & 0.27 & & 6.75 & 13.50 & 3.40 & 26.43 & $\begin{array}{r}73.57 \\
+\end{array}$ & 11.58 & 2.99 & 3.56 & 9.94 & 1.54 & 0.41 \\
\hline $256(47)$ & $\begin{array}{r}25.05 \\
+\end{array}$ & 5.24 & 2.20 & 0.40 & 1.10 & 0.34 & 40.00 & 6.0 & 12.10 & 4.00 & 29.94 & 70.06 & 11.94 & 3.63 & 3.65 & 8.45 & 1.40 & 0.45 \\
\hline 26 (139) & 16.94 & $\begin{array}{r}9.20 \\
+\end{array}$ & 2.50 & 0.37 & 1.30 & 0.30 & 33.50 & 5.95 & 11.90 & 3.70 & 29.86 & & 12.69 & $\begin{array}{r}4.01 \\
+\end{array}$ & 3.53 & 8.37 & 1.49 & 0.47 \\
\hline $261(375)$ & $\begin{array}{r}19.35 \\
+\end{array}$ & $\begin{array}{r}5.77 \\
+\end{array}$ & 2.60 & $\begin{array}{r}0.56 \\
+\end{array}$ & $\begin{array}{r}1.60 \\
+\end{array}$ & $\begin{array}{r}0.51 \\
+\end{array}$ & 51.50 & $9.65+$ & $\begin{array}{r}19.30 \\
+\end{array}$ & $\begin{array}{r}5.60 \\
+\end{array}$ & 29.12 & $\begin{array}{r}70.88 \\
+\end{array}$ & 10.72 & 2.87 & $\begin{array}{r}5.67 \\
+\end{array}$ & $\begin{array}{r}13.63 \\
+\end{array}$ & 2.13 & 0.56 \\
\hline & 15.50 & $\begin{array}{r}6.35 \\
+\end{array}$ & 2.40 & 0.30 & 1.10 & 0.25 & 47.00 & 6.40 & 12.80 & 3.00 & 29.24 & $\begin{array}{r}70.76 \\
+\end{array}$ & 10.52 & 3.59 & 3.75 & 9.05 & 1.35 & 0.46 \\
\hline $264(493)$ & $\begin{array}{r}23.85 \\
+\end{array}$ & $\begin{array}{r}7.68 \\
+\end{array}$ & 2.70 & $\begin{array}{r}0.56 \\
+\end{array}$ & 1.30 & $\begin{array}{r}0.48 \\
+\end{array}$ & 51.00 & $\begin{array}{r}11.15 \\
+\end{array}$ & $\begin{array}{r}22.30 \\
+\end{array}$ & $\begin{array}{r}5.60 \\
+\end{array}$ & $\begin{array}{r}31.26 \\
+\end{array}$ & 68.74 & 10.73 & $\begin{array}{r}4.08 \\
+\end{array}$ & $\begin{array}{r}6.98 \\
+\end{array}$ & $\begin{array}{r}15.32 \\
+\end{array}$ & $\begin{array}{r}2.39 \\
+\end{array}$ & $\begin{array}{r}0.91 \\
+\end{array}$ \\
\hline $272(632)$ & $\begin{array}{r}20.52 \\
+\end{array}$ & 5.28 & 1.30 & 0.26 & 0.90 & 0.23 & 29.50 & 5.10 & 10.20 & 2.60 & 28.74 & $\begin{array}{r}71.26 \\
+\end{array}$ & 10.03 & 3.62 & 2.88 & 7.32 & 1.02 & 0.33 \\
\hline 28 (106) & 18.00 & 5.10 & 4.40 & 0.46 & 2.00 & 0.34 & $86.50+$ & $8.85+$ & 17.70 & 4.60 & 31.83 & 68.17 & 15.20 & 3.80 & 5.64 & 12.06 & 2.68 & 0.68 \\
\hline
\end{tabular}




\begin{tabular}{|c|c|c|c|c|c|c|c|c|c|c|c|c|c|c|c|c|c|c|}
\hline Genotip & 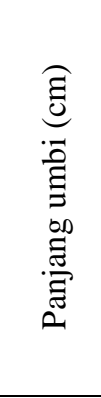 & 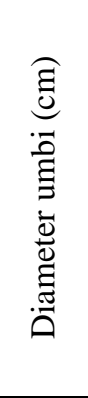 & 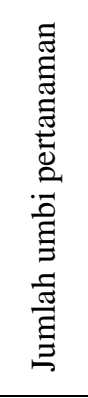 & 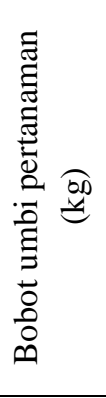 & 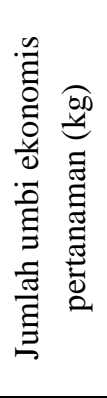 & 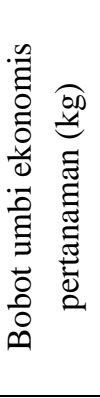 & 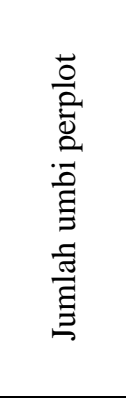 & 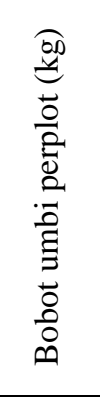 & 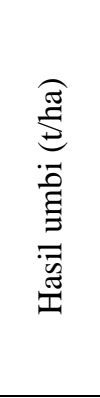 & 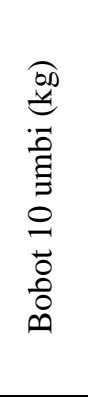 & 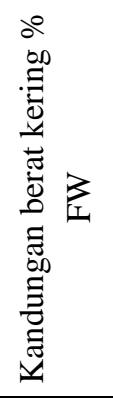 & 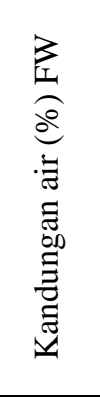 & 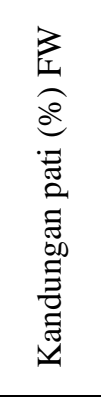 & 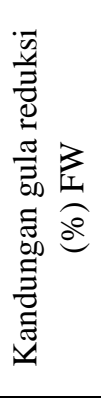 & 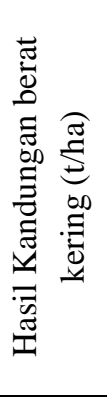 & 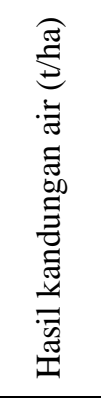 & 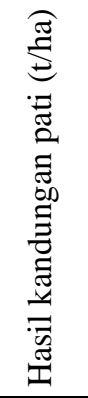 & 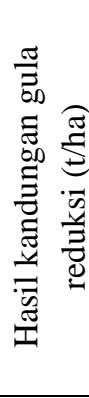 \\
\hline & & & + & + & + & & & & + & + & + & & + & + & + & & + & + \\
\hline $300(635)$ & 13.95 & 3.31 & 1.50 & 0.19 & 0.70 & 0.06 & 36.50 & 4.60 & 9.20 & 1.90 & 30.00 & 70.00 & 11.41 & 3.70 & 2.88 & 6.32 & 0.97 & 0.36 \\
\hline \multirow{2}{*}{$42(10)$} & \multirow{2}{*}{18.50} & 5.78 & 3.50 & 0.54 & 2.40 & 0.48 & \multirow{2}{*}{$66.50+$} & 11.00 & 22.00 & 5.40 & 31.92 & \multirow{2}{*}{68.08} & 14.71 & 4.04 & 6.97 & 15.03 & 3.18 & 0.87 \\
\hline & & + & + & + & + & + & & + & + & + & + & & + & + & + & + & + & + \\
\hline $\begin{array}{l}\text { Ayamurasa } \\
\mathrm{ki}\end{array}$ & 16.05 & 3.65 & $\begin{array}{r}3.45 \\
+\end{array}$ & 0.31 & $\begin{array}{r}1.55 \\
+\end{array}$ & 0.25 & $65.63+$ & 5.35 & 10.70 & 3.13 & 29.72 & $\begin{array}{r}70.28 \\
+\end{array}$ & $\begin{array}{r}13.01 \\
+\end{array}$ & 3.65 & 3.24 & 7.46 & 1.45 & 0.40 \\
\hline \multirow{2}{*}{ CIA } & \multirow{2}{*}{17.65} & 7.43 & 4.29 & 0.59 & 2.27 & 0.48 & \multirow{2}{*}{$74.54+$} & 10.78 & 21.57 & 5.88 & \multirow{2}{*}{29.88} & 70.12 & \multirow{2}{*}{11.67} & \multirow{2}{*}{3.50} & 6.46 & 15.11 & 2.53 & \multirow{2}{*}{$\begin{array}{r}0.76 \\
+\end{array}$} \\
\hline & & + & + & + & + & + & & + & + & + & & + & & & + & + & + & \\
\hline KUPUT & 13.81 & $\begin{array}{r}5.91 \\
+\end{array}$ & 2.92 & 0.41 & $\begin{array}{r}1.54 \\
+\end{array}$ & 0.34 & 57.92 & 8.41 & 16.83 & 4.08 & 29.91 & 70.09 & $\begin{array}{r}13.23 \\
+\end{array}$ & 3.22 & 5.12 & 11.71 & $\begin{array}{r}2.35 \\
+\end{array}$ & 0.55 \\
\hline \multirow{2}{*}{ Rancing } & \multirow{2}{*}{17.79} & \multirow{2}{*}{4.92} & 4.15 & 0.52 & 2.13 & 0.44 & \multirow{2}{*}{$83.75+$} & 10.95 & 21.89 & 5.23 & \multirow{2}{*}{29.32} & 70.68 & \multirow{2}{*}{12.61} & \multirow{2}{*}{3.48} & 6.40 & 15.49 & 2.74 & 0.75 \\
\hline & & & + & + & + & + & & + & + & + & & + & & & + & + & + & + \\
\hline Shiroyutaka & 15.02 & $\begin{array}{r}5.89 \\
+\end{array}$ & 2.36 & 0.32 & 1.29 & 0.29 & 41.33 & 5.70 & 11.39 & 3.18 & 30.35 & 69.65 & 12.31 & 3.72 & 3.47 & 7.92 & 1.40 & 0.43 \\
\hline Rta-rata & 17.99 & 5.27 & 3.02 & 0.40 & 1.41 & 0.33 & 57.95 & 7.75 & 15.51 & 4.02 & 30.28 & 69.72 & 12.53 & 3.65 & 4.70 & 10.81 & 1.94 & 0.57 \\
\hline $\begin{array}{l}\text { Standar } \\
\text { error }\end{array}$ & 0.52 & 0.19 & 0.17 & 0.02 & 0.06 & 0.02 & 3.16 & 0.45 & 0.89 & 0.24 & 0.19 & 0.19 & 0.18 & 0.04 & 0.26 & 0.63 & 0.11 & 0.03 \\
\hline
\end{tabular}

Keterangan : tanda + menunjukkan nilai lebih tinggi dari penampilan rata-rata pada taraf uji t $5 \%$ 


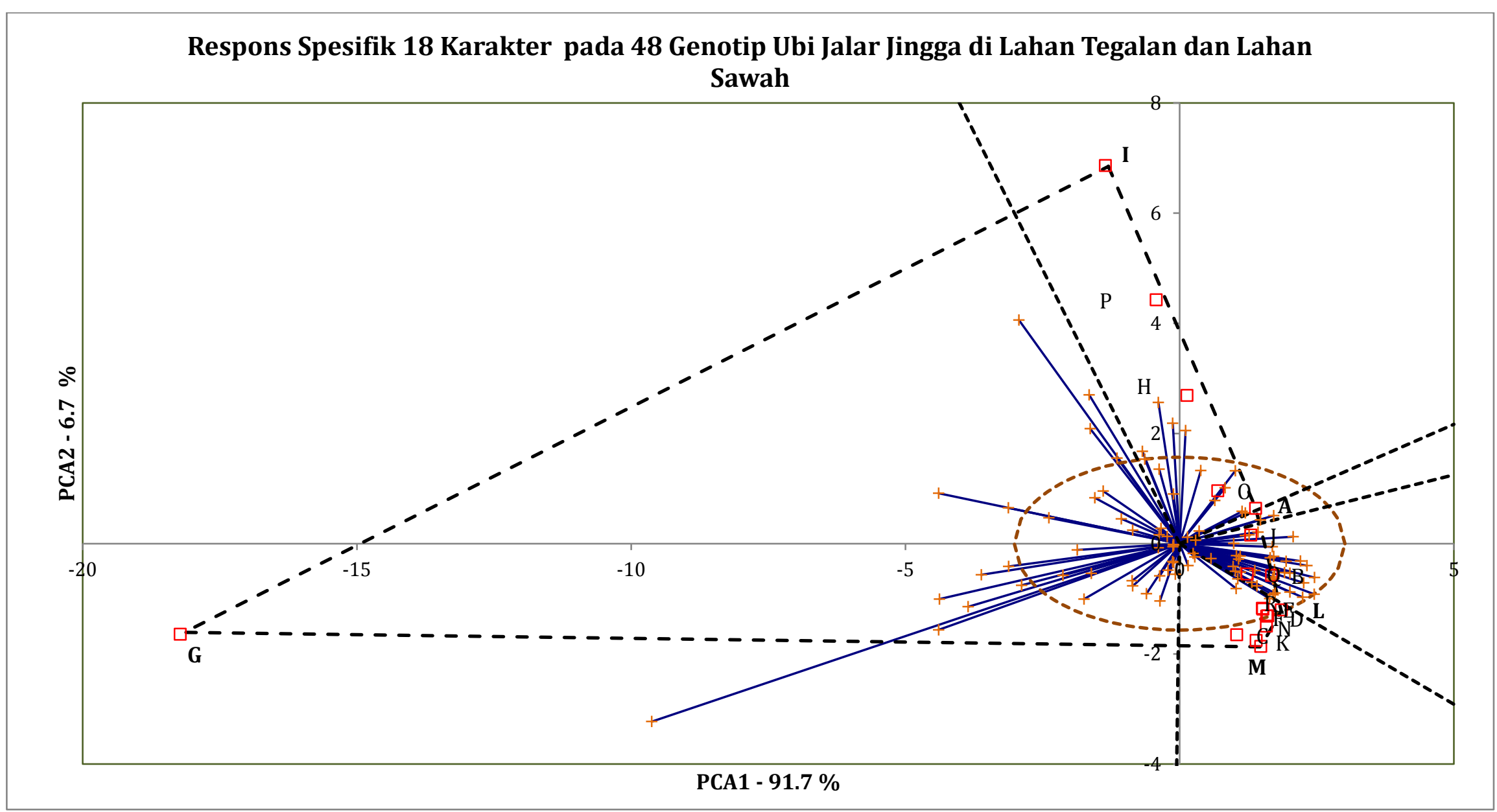

Gambar 1. Biplot respons spesifik karakter pada 48 genotip ubi jalar jingga di lahan tegalan dan lahan sawah.

Keterangan : + genotip, $\square$ karakter. 


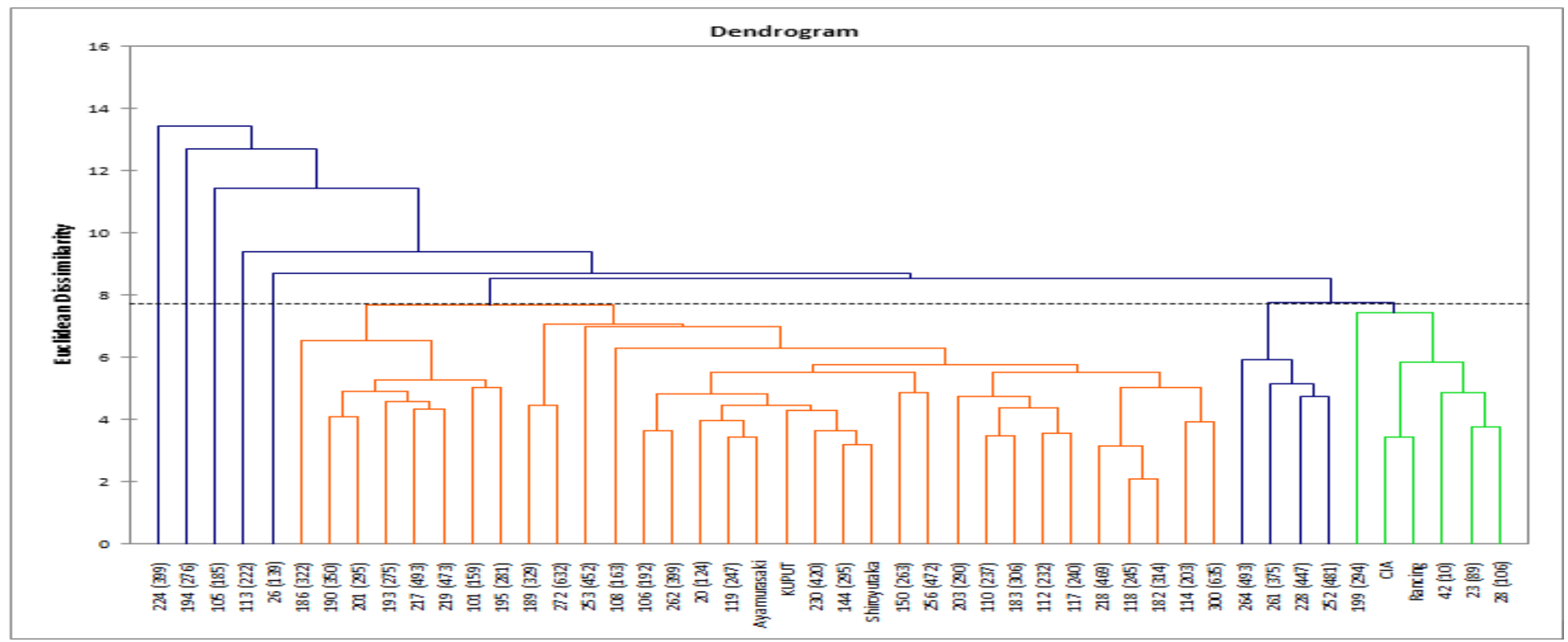

Gambar 2. Delapan Kelompok Genotip Berdasarkan Respons 18 Karakter Genotip Ubi Jalar Jingga di Lahan tegalan dan lahan Sawah 